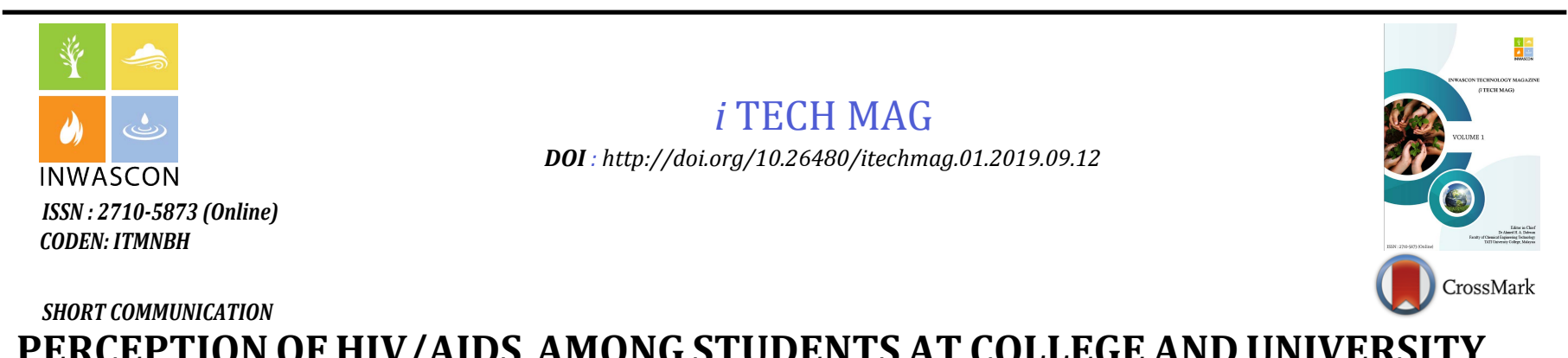

\title{
PERCEPTION OF HIV/AIDS AMONG STUDENTS AT COLLEGE AND UNIVERSITY
}

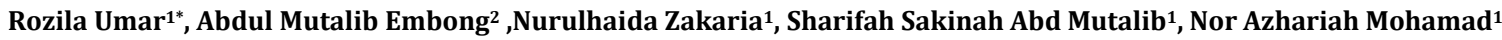

\author{
${ }^{1}$ TATI University Collge, TATIUC, 24000, Kemaman, Terengganu, Malaysia \\ ${ }^{2}$ Universiti Teknologi PETRONAS, UTP, 32610, Seri Iskandar, Perak, Malaysia \\ *Corresponding author email: rozila@Ttatiuc,edu.my
}

This is an open access article distributed under the Creative Commons Attribution License, which permits unrestricted use, distribution, and reproduction in any medium, provided the original work is properly cited.

\section{ARTICLE DETAILS}

\section{Article History:}

Received 30 August 2019 Accepted 10 September 2019 Available online 20 September 2019

\section{ABSTRACT}

The purpose of this study to describe students' perception of HIV/AIDS and individuals with HIV/AIDS while they are studying at University or college. This study has used the concept of perception to capture students' attitudes, knowledge and feeling toward HIV/AIDS and individuals with HIV/AIDS. The data were collected by using a questionnaire. A simple random sample of 252 pre-degree or matriculation, diploma and degree students where $53.6 \%$ or 135 male and $46.4 \%$ or 117 females. The results show that majority students have a good knowledge concerning HIV/AIDS but they were refused to deal with person who infected with the virus. The significant value gives us a value of 0.058 for general knowledge which gives us an interpretation that there is no difference between each level of education and their knowledge regarding HIV/AIDS. However, for variable named as attitude, the significant value is 0.000 which lead us to an interpretation that at least one level of education is having a different mean compare to other level of education.

\section{KEYWORDS}

Perception, HIV/AIDS, Attitude, Knowledge, Students.

\section{INTRODUCTION}

HIV is the infection that attacks the immune system, and debilitates the capacity to fight against the virus and diseases; AIDS is the terminal stage of HIV disease, when human body can no longer fight life-threatening infections. In the past few decades HIV/AIDS have been affecting populace everywhere throughout the world contrarily in different ways. Since 1986 when the first case of HIV was detected, Malaysia emerges the disease as a controversial health problem. Over 100,000 reported cases of HIV infections in the country, and over 16,000 people have died from AIDS as of December 2013

From that point forward, the total accumulative cases as of 2010 of HIV contamination in the country are added up to an aggregate of 91,362 cases of HIV and 16,352 cases of AIDS ("HIV/AIDS in Malaysia", 2019). These results particularly alarm the way that HIV disease rate and AIDS cases are demonstrating a fast increment in Malaysia.

Internationally, people aged from $15-24$ years represent around $45 \%$ of new HIV infections and this is valid in some Asian countries like Malaysia, where HIV contaminations happen basically among youngsters (Wong, Chin, Low \& Jaafar, 2008). There are around 70,000 individuals living with HIV in which the biggest numbers of those contaminated are youthful Malaysian between the ages 20 to 39 ("HIV/AIDS in Malaysia", 2019). In fact, there is most likely that young people are at higher risk getting HIV/AIDS, than other aged groups, reason why the increasing rate of HIV/AIDS continues to be a wellspring of incredible concern inside universities.

The pattern among youths and youthful adults headed for high-hazard behavior combined with lack of education are the main whys and wherefores behind the expansion in transmission of HIV. Besides that, a troubling part of this epidemic disaster is that the disease affects Malaysians in their crucial gainful ages (Wong et al., 2008). It is well documented that people infected by the virus which has no particular cure, can only betake for preventive measures that is contributed by educational programs and relevant information. These measures are essential for handling HIV/AIDS and its associated issues. Moreover, university students constitute and essential group in the mediation against the disease. Therefore, understanding students' personality and individuals' differences towards HIV/AIDS plays a crucial role in counseling the general society, particularly students for the prevention and control of the illness (Wong et al., 2008).

Ebot (2009) and Haroun (2016) study about the perceptions of university students towards HIV/AIDS. Ebot (2009) found that knowledge did not have an effect on the level of beliefs and prejudices of the students and religion had no great influence on the students' perceptions. Whereas, Haroun (2016) found that misconceptions about modes of transmission of HIV/AIDS, overall knowledge on HIV/AIDS and stigmatizing attitudes towards people living with HIV/AIDS continue to exist among university students in UAE. No significant differences between males and females and marital status also were found in that study. Hence, the objectives of this study are to investigate student's perception of HIV/AIDS and the relation of student's perception between gender and their level of education.

\section{METHODOLOGY}

A questionnaire was distributed to 252 students from various institutions aged from 18 to 26 years old. The questionnaire consists of 4 main sessions with a total of 34 questions to examine the students on their demographic (section A), general attitude (section B), general knowledge (section C) and lastly their precise knowledge testing (section D). Three factors which were attitude, knowledge and precise knowledge represent students' perceptions. For section B, dichotomous scales were used. While in section C, 3-Likert scale which options (1) true (2) false and (3) don't know was used. Lastly, for section D 5-Likert scale was used in the questionnaire range from strongly disagree to strongly agree.

Firstly, the respondents were asked to analyze a slide share which was based on demonstration of 15 pictures of HIV victims that consist of kids and adults. Next, one short video demonstrations were played to the respondents. The video had duration of 8 minutes. This video is played to show to make sure the respondent have a better idea about the disease. 
Lastly, the respondents were given a questionnaire to answer within 15 minutes in which they were inquired about their personality individual differences between HIV/AIDS.

Reliability analysis was conducted first in order to measure the reliability of the questionnaire. Correlation and analysis of variance was conducted to investigate the relationship and measure the significance of student's perception between gender and their level of education. In this survey, we transfer the value into percentage value. Our data were then analyzing using SPSS software.

\section{RESULTS AND DISCUSSION}

\subsection{Reliability Analysis}

Prior to further data collection, in the pilot study, the reliability coefficient alpha was used to measure the reliability of the construct. The sample for the pilot study comprised of 252 respondents. Table 1 shows the items and cronbach alpha of each factor respectively. The cronbach alpha value for each factor is more than 0.6 except for general attitudes factor. Therefore the scale questions are consistent and thus reliable for this research.

Table 1: Cronbach Alpha on reliability test

\begin{tabular}{lll}
\hline Factor & No. Of Items & Cronbach Alpha \\
\hline General knowledge & 10 & 0.632 \\
Precise attitudes & 14 & 0.898 \\
\hline
\end{tabular}

\subsection{Demographic}

This research involving 252 students ages from 18 to $26.38 .5 \%$ of the students are 19 years old. The students are taken from three different level of education that is Pre-University or Matriculation (Pre-U), Diploma level and Degree level. $34.1 \%$ of the respondents are taken from diploma level. Among the respondent $53.6 \%$ were male while $46.4 \%$ was female. A questionnaire was distributed to the respondent, and they were given few minutes to answer a few question regarding HIV and AIDS.

Table 2: Total Percentage of Respondent for gender and level of education

\begin{tabular}{lll}
\hline & Frequency & Percentage \\
\hline Gender & & \\
Male & 135 & $53.6 \%$ \\
Female & 117 & $46.4 \%$ \\
\hline Level of Education & & \\
Pre-U & 82 & $32.5 \%$ \\
Diploma & 86 & $34.1 \%$ \\
Degree & 84 & $33.3 \%$ \\
\hline
\end{tabular}

In order to measure the students' knowledge of HIV and AIDS, they were asked to indicate their answers on a various statement regarding HIV and AIDS either it is true, false or they don't have any idea regarding the statement. $92.8 \%$ of the respondent answered true to the statement saying that individuals who practice unprotected sex and intravenous drug abusers were the high risk of contracting HIV and AIDS. They (70.8\%) understood that there is no cure for AIDS. Majority of the students (90.5\%) know that HIV can be transmitted by blood and $88.5 \%$ know that people can get HIV by sharing needles with drug users who has AIDS.
Table 3: Analysis about General Knowledge

\begin{tabular}{|c|c|c|c|}
\hline Question about general knowledge & True & False & $\begin{array}{l}\text { No } \\
\text { idea }\end{array}$ \\
\hline $\begin{array}{l}\text { 1. AIDS is a disease that strikes at the } \\
\text { human immune system. }\end{array}$ & $83.3 \%$ & $0.8 \%$ & $15.9 \%$ \\
\hline 2. There is no cure for AIDS. & $70.6 \%$ & $14.7 \%$ & $14.7 \%$ \\
\hline $\begin{array}{l}\text { 3. Individuals at high risk for contracting } \\
\text { HIV include intravenous drug abuser, } \\
\text { those who practice unprotected sex and } \\
\text { prostitutes. }\end{array}$ & $92.8 \%$ & $2.4 \%$ & $4.8 \%$ \\
\hline $\begin{array}{l}\text { 4. A positive HIV antibody test means that } \\
\text { the person has AIDS. }\end{array}$ & $57.9 \%$ & $17.9 \%$ & $24.2 \%$ \\
\hline $\begin{array}{l}\text { 5. The HIV is found in high concentration } \\
\text { in saliva, tears and urine. }\end{array}$ & $28.2 \%$ & $29 \%$ & $42.9 \%$ \\
\hline 6. AIDS is a lethal disease. & $88.1 \%$ & $2.8 \%$ & $9.1 \%$ \\
\hline $\begin{array}{l}\text { 7. AIDS is caused by a virus similar to that } \\
\text { which causes other venereal disease. }\end{array}$ & $37.7 \%$ & $17.5 \%$ & $44.8 \%$ \\
\hline $\begin{array}{l}\text { 8. People can get HIV by sharing a needle } \\
\text { with a drug user who has AIDS. }\end{array}$ & $88.5 \%$ & $5.2 \%$ & $6.3 \%$ \\
\hline $\begin{array}{l}\text { 9. HIV can be transmitted by blood and } \\
\text { blood products. }\end{array}$ & $90.5 \%$ & $2.4 \%$ & $7.1 \%$ \\
\hline $\begin{array}{l}\text { 10. HIV can be transmitted by causal } \\
\text { contact with persons who have the } \\
\text { disease. }\end{array}$ & $17.5 \%$ & $67.1 \%$ & $15.5 \%$ \\
\hline
\end{tabular}

To gain more idea either the student has knowledge on HIV/AIDS, they were asked to answer a statement "do you have enough information of HIV/AIDS". The following percentages were obtained as shown in the table below. It shows that $81.7 \%$ says they don't have enough information of HIV/AIDS.

Table 4: Total Percentage of Respondent for General Attitude

\begin{tabular}{|c|c|c|}
\hline General attitude & Frequency & Percent \\
\hline yes & 46 & 18.3 \\
\hline no & 206 & 81.7 \\
\hline Total & 252 & 100.0 \\
\hline
\end{tabular}

A few statement been asked to the respondent regarding their attitude if they were dealing with the person with HIV/AIDS. $97.2 \%$ of the respondent never been asked and never have any experienced on dealing with HIV/AIDS person. $87.7 \%$ of them even did not know a family member, friends or another person with HIV and AIDS. Balance 12.3\% must have known somebody with HIV/AIDS but did not have experience to take care of them.

The respondent were also asked either they are willing to care for a person with HIV/AIDS. 52.4\% (132) of the respondent are not willing to care for a person with HIV or AIDS. Table below summarize the percentage for the statement asked to the student regarding their attitude. 1 is for strongly agree statement while 5 is for strongly disagree statement.

Table 5: Total Percentage of Respondent for Precise Attitude

\begin{tabular}{|c|c|c|c|c|c|}
\hline QUESTION & 1 & 2 & 3 & 4 & 5 \\
\hline $\begin{array}{l}\text { 1. I am /would be fearful of contracting HIV if I am dealing with } \\
\text { people with HIV. }\end{array}$ & $29.4 \%$ & $30.6 \%$ & $21.8 \%$ & $11.5 \%$ & $6.7 \%$ \\
\hline $\begin{array}{l}\text { 2. I should have the right to refuse to deal with persons with HIV } \\
\text { or AIDS. }\end{array}$ & $22.6 \%$ & $30.6 \%$ & $32.1 \%$ & $11.5 \%$ & $3.2 \%$ \\
\hline 3. I would refuse to care for a person with HIV or AIDS. & $14.3 \%$ & $11.9 \%$ & $45.2 \%$ & $20.6 \%$ & $7.9 \%$ \\
\hline $\begin{array}{l}\text { 4. Health care institutions should have the right to refuse to } \\
\text { provide care to patients with HIV or AIDS. }\end{array}$ & $11.1 \%$ & $5.6 \%$ & $15.1 \%$ & $25.4 \%$ & $42.9 \%$ \\
\hline $\begin{array}{l}\text { 5. To care for people with HIV or AIDS should be based on } \\
\text { voluntary basis only. }\end{array}$ & $18.7 \%$ & $20.2 \%$ & $25.8 \%$ & $23.0 \%$ & $12.3 \%$ \\
\hline $\begin{array}{l}\text { 6. People with HIV or AIDS should be cared for in a separate unit } \\
\text { with specifically trained personnel. }\end{array}$ & $46.8 \%$ & $28.2 \%$ & $14.3 \%$ & $8.7 \%$ & $2.0 \%$ \\
\hline $\begin{array}{l}\text { 7. Those who care for people with HIV or AIDS should receive } \\
\text { additional pay. }\end{array}$ & $25.4 \%$ & $19.4 \%$ & $37.3 \%$ & $10.7 \%$ & $7.1 \%$ \\
\hline 8. If I dealt with a person with HIV or AIDS, I would worry about & $26.6 \%$ & $30.2 \%$ & $23.8 \%$ & $13.5 \%$ & $6.0 \%$ \\
\hline
\end{tabular}


putting my family, friends and colleague at risk.

9. Dealing with people with HIV or AIDS has/could affect my $12.7 \%$ relationship with significant others.

10. I would prefer not to provide care to people with HIV or AIDS $7.9 \%$

because of the hopelessness of the prognosis.
11. Caring for a person who is dying is uncomfortable to me.

12. I do not feel it is worthwhile for me to expend my time and energy caring for a person with AIDS who is dying.

13. I would not want to be assigned to people with HIV or AIDS because I do not feel competent to meet their intense physical needs.

14. I would not want to be assigned to people with HIV or AIDS

$8.7 \%$

$8.3 \%$

$12.3 \%$

because I do not feel competent to deal with their intense psychological needs.

\begin{tabular}{llll}
$20.6 \%$ & $30.6 \%$ & $24.6 \%$ & $11.5 \%$ \\
$13.9 \%$ & $27.4 \%$ & $31.3 \%$ & $19.4 \%$ \\
$12.3 \%$ & $31.7 \%$ & $21.0 \%$ & $26.2 \%$ \\
$7.9 \%$ & $23.4 \%$ & $34.9 \%$ & $25.4 \%$ \\
$21.0 \%$ & $34.5 \%$ & $23.0 \%$ & $9.1 \%$ \\
& & & \\
$22.2 \%$ & $33.7 \%$ & $20.2 \%$ & $8.3 \%$ \\
& & & \\
\hline
\end{tabular}

Table 8: T-Test and significant value

(he table 5, 46.8\% agreed that people with HIV or AIDS should be cared for in a separate unit with specifically trained personnel. On the other hand, the students show a good attitude by disagree (42.9\%) to the statement that the healthcare institution should refuse to provide care to patients with HIV or AIDS. Only $14.3 \%$ of the student agreed to the statement that they refuse to care for a person with HIV or AIDS while $45.2 \%$ still undecided either to care or not.

A few students, which are $26.6 \%$ of them, agreed to the statement that they worried if dealing with person with HIV or AIDS will put their family friends and colleagues at risk. Only $12.7 \%$ agreed that they also worried it may affected their relationship with significant persons if they deal will HIV/AIDS person.

\subsection{Analysis of Variance (ANOVA)}

An ANOVA test was constructed to identify either there has been any mean difference between the level of education and the general knowledge on HIV/ AIDS and also on their attitude towards persons with HIV/AIDS. The significant value gives us a value of 0.058 for general knowledge which gives us an interpretation that there is no difference between each level of education and their knowledge regarding HIV/AIDS. However, for variable named as attitude, the significant value is 0.000 which lead us to an interpretation that we will reject null hypothesis. Therefore, we can say that at least one level of education is having a different mean compare to other level of education.

Table 6: ANOVA Test for General Knowledge and Precise Attitude

\begin{tabular}{llll}
\hline & & F & Sig. \\
\hline General knowledge & Between Groups & 2.882 & .058 \\
& Within Groups & & \\
& Total & & \\
Precise attitude & Between Groups & 16.507 & .000 \\
& Within Groups \\
& Total & & \\
\hline
\end{tabular}

A further analysis then constructed to identify at least which level of education is different to one another. Just looking at the significant value, if the value is smaller than 0.05 , we then can say that the mean are different, otherwise, it is equal. Based on the below table, it shows that the attitudes of degree student are different compare to the diploma and Pre-U student.

Table 7: Test of difference means between level of education

\begin{tabular}{lllll}
\hline \multirow{2}{*}{ (I) Education } & (J) Education & Mean Difference & & \\
\hline \multirow{2}{*}{ Pre-U } & Diploma & -.03661 & Std. Error & Sig. \\
\cline { 2 - 5 } & Degree & $-.57954^{*}$ & .11291 & .746 \\
\hline \multirow{2}{*}{ Diploma } & Pre-U & .03661 & .11297 & .000 \\
\cline { 2 - 5 } & Degree & $-.54293^{*}$ & .11222 & .000 \\
\hline
\end{tabular}

An analysis was also done to see if there is any difference between the mean knowledge and attitude between female and male student. The significant value for each variable showed a value that is greater than 0.05 which lead us to a conclusion that there is no different between the mean attitude and knowledge between female and male student.

\begin{tabular}{llll}
\hline & $\mathrm{t}$ & $\mathrm{df}$ & Sig.(2-tailed) \\
\hline Precise attitude & & & \\
& 0.505 & 250 & 0.614 \\
\hline General knowledge & & & \\
& 1.513 & 250 & 0.132 \\
\hline
\end{tabular}

\section{CONCLUSION}

This study found that there is a significant difference between the student perception and their level of education. However, only students at degree level have different perceptions compare to students at diploma and PreU level regarding HIV/AIDS.

For example, the students had a realistic perception of risk towards HIV/AIDS, especially if they engage in unhealthy behaviour. The students have a general knowledge about related issues even though almost all of them did not have experienced. They understood that there is no cure yet for HIV/AIDS. A majority (92.8\%) of the students agreed that those who practiced unprotected sex with increasing partners, sharing needles with intravenous drug users are at high risk of contracting HIV/AIDS. Because of that, most of the students feel a bit afraid of people who have HIV/AIDS.

\section{ACKNOWLEDGEMENT}

We would like to express our very great appreciation to our friends for valuable and constructive suggestions during the planning and development of this study. Their willingness to give their time so generously has been very much appreciated. Finally, we wish to thank our parents and family for their support and encouragement throughout our study.

\section{REFERENCES}

[1] Haroun, D., EL Saleh, O. Wood, L., Mechli, R., Al Marzouqi, N., \& Anouti, S. (2016). Assessing Knowledge of, and Attitudes to HIV/AIDS among University Students in the United Arab Emirates. PLoS ONE 11(2), 1-11.

[2] Ebot, M. E., (2009). Perception of HIV/AIDS among Students at the University of Joensuu (Master's Thesis).

[3] Wong, L-P., Chin, C-K. L., Low, W-Y \& Jaafar, N. (2008). HIV/AIDSRelated Knowledge among Malaysia Young Adults: Findings from a Nationwide Survey. Journal of the International AIDS Society 10(148). 1-9. [4] Adam, Barry D. (1989). The state, public policy and AIDS Discourse, Contemporary Crises. 13:1-14

[5] Altman, D. (1987). Aids in the mind of American Garden City, NY:Doubleday. Pp. 162

[6] Berk, R. (1987). Anticipating the social consequences of AIDS. American sociology. 18:3.

[7] Lawson, A.L-G. 1999. Women and AIDS in Africa: Socio-cultural Dimension of the HIV/AIDS Epidermic. 
[8] Homan, H., Aggleton,P.J. \& Warwick, I. (1987). Learning about AIDSInterim materials, London, health education authority/ AVERT.

[9] Huber,J.\& Schnider,B.E.(1992) The social context of AIDS.
[10] Iliffe, J. (2006). A history: The African AIDS Epidermic.

[11] Kaplan,H., Johnson, R., Bailey, C.\& Simon,W. (1987). The sociological study of AIDS. Journal of health and social behavior 28:140-57. 